\title{
The effects of foliar pubescence and nutrient enrichment on arthropod communities of Metrosideros polymorpha (Myrtaceae)
}

\author{
DANIEL S. GRUNER ${ }^{1}$, ANDREW D. TAYLOR ${ }^{1}$ and REBECCA \\ E. FOR K NE R ${ }^{2}{ }^{1}$ Department of Zoology, University of Hawai'i at Mānoa, Hawaíi, U.S.A and ${ }^{2}$ Department of \\ Biology, University of South Florida, Florida, U.S.A.
}

\begin{abstract}
Nutrient resource availability and host-plant foliar pubescence both influence arthropod food webs, but multifactor studies are needed to understand their interdependence and relative importance. Arthropods were sampled by clipping foliage from Metrosideros polymorpha (Myrtaceae) trees of pubescent, glabrous, and intermediate leaf forms on fertilised and unfertilised plots.

2. Fertilisation decreased leaf mass per area (LMA) but did not change the relative mass of pubescence within leaf morphological classes.

3. Fertilisation increased densities of individuals in four taxonomic orders, densities of individuals and species of all trophic levels, and the biomass of Collembola and Homoptera. Herbivore relative diversity (Shannon $H^{\prime}$ ) also increased with fertilisation, but detritivore diversity declined due to increasing dominance of Salina celebensis (Schaeffer) (Collembola).

4. Detritivore density, driven again by $S$. celebensis, increased with decreasing leaf pubescence, but Heteroptera and Acari were most abundant on the intermediate pubescence class, and Psocoptera density and biomass increased with increasing pubescence. Trophic-level species density did not change with leaf morphological class, but relative diversity of all arthropods and of detritivores increased with increasing pubescence.

5. Both resource availability and leaf pubescence affected Metrosideros arthropod communities. However, the pervasive positive influence of fertilisation did not translate to compositional shifts, and there were no interactions with leaf morphological class. In contrast, the effects of leaf pubescence on arthropod density, biomass, and diversity were more restricted taxonomically, and nonparametric MANOVA and redundancy analyses demonstrated significant differentiation in community composition on the pubescent morphology.
\end{abstract}

Key words. Arthropod community structure, bottom-up control, fertilisation, Hawaiian Islands, non-parametric MANOvA, redundancy analysis, species richness and diversity, trichomes.

Correspondence: Dr Daniel S. Gruner, Bodega Marine Laboratory, University of California-Davis, PO Box 247, Bodega Bay, CA 94923-0247, U.S.A. E-mail: dsgruner@ucdavis.edu

\section{Introduction}

The search for factors that regulate community-level properties has identified a suite of bottom-up forces that constrain relative abundance and diversity within food webs. The supply of limited nutrient resources is of 
fundamental importance to plant productivity and to the arthropod populations and communities on plants (White, 1984; Waring \& Cobb, 1992; Kytö et al., 1996). Ambient plant nitrogen levels are low in comparison to consumer requirements (Mattson, 1980; White, 1984; Hartley \& Crawley, 1997), and a wide variety of herbivore taxa feed preferentially on nitrogen-enriched tissues (Ball et al., 2000; Nakamura et al., 2003; Albrectsen et al., 2004). The abundance, biomass, and diversity of herbivores or detritivores and their predators often increase in fertilisation experiments in natural systems (e.g. Levine et al., 1998; Scheu \& Schaeffer, 1998; Siemann, 1998; Haddad et al., 2000; Ritchie, 2000; Halaj \& Wise, 2002).

Bottom-up effects also can arise from variation in resource attributes other than simply the supply of nutrients, and these may interact with nutrient levels to produce emergent impacts on insect communities. For example, the response of arthropods to fertilisation may be mediated by plant architecture, and increased resources can alter plant physical structure, habitat complexity, or species composition (Siemann, 1998; Haddad et al., 2000; Orians \& Jones, 2001; Denno et al., 2002; Langellotto \& Denno, 2004). Changes in abiotic factors, such as shading, may alter host-plant morphology in ways that influence herbivore attack and the success of their enemies (Craig, 1994; Moon et al., 2000). Other sources of bottom-up heterogeneity, such as soil salinity (Moon \& Stiling, 2002), water supply (Huberty \& Denno, 2004), and intraspecific variation in host chemistry (Forkner et al., 2004) or physical morphology (Moon et al., 2000; Hare \& Elle, 2002), can also interact with nutrient supply to affect arthropod communities.

Leaf pubescence - the presence of trichomes - may act as a chemical or mechanical defence to herbivores (Levin, 1973; Juniper \& Southwood, 1986; Gruenhagen \& Perring, 1999). Trichomes can secrete secondary chemicals (Stipanovic, 1983), or they may be composed of inert lignins and cellulose that inhibit digestion (Levin, 1973; Juniper \& Southwood, 1986). Trichomes can prevent herbivores from coming into contact with a leaf without first removing or consuming the pubescence, or may be directly harmful or fatal to insects (Pillemer \& Tingey, 1976; Eisner et al., 1998). Mattson et al. (1988) predicted that herbivores can evolve to escape pubescence by reducing their 'intimacy of association': by avoidance or reduction of contact time with pubescence or by growing larger relative to hair size or density. Numerous studies have shown decreased herbivory or arthropod abundance on pubescent phenotypes relative to glabrous forms (Levin, 1973; Turnipseed, 1977; Schoener, 1987; Gruenhagen \& Perring, 1999; Andres \& Connor, 2003; but see van Dam \& Hare, 1998; Roda et al., 2001). However, few studies have investigated how resource availability influences plant trichomes and the effects of pubescence on arthropod populations or communities (Wellso \& Hoxie, 1982; Wilkens et al., 1996; Roy et al., 1999).

Metrosideros polymorpha Gaudichaud-Beaupré (Myrtaceae) is a morphologically variable tree dominant in numerous ecosystem types throughout the Hawaiian Islands. There are eight described varieties of $M$. polymorpha, characterised by growth form, leaf size, and shape and the density of trichomes on the leaves and stems (Dawson \& Stemmerman, 1999). The distribution of morphological types generally follows broad abiotic gradients that may be associated with nutrient resource supply, with thick-leaved pubescent forms dominant at higher elevation and on young volcanic substrates (Corn \& Hiesey, 1973; Kitayama \& Mueller-Dombois, 1992; Geeske et al., 1994). However, multiple phenotypes, ranging from completely glabrous to densely tomentose forms, often coexist in sympatric populations on young basalt lava flows at intermediate elevations (Stemmermann, 1983). A diversity of arthropods attack or process the dead wood and litter of M. polymorpha (Gruner, 2004a). Many of the herbivorous species attack buds before leaf hairs are well developed and avoid contact with pubescence through endophagous habits. Nevertheless, pubescent forms of M. polymorpha appear more resistant to, or less favoured by, most of these herbivores (Lee, 1981; D. S. Gruner, unpublished data).

This study sought to disentangle the community-wide responses of arthropods to nutrient resources and foliar pubescence of $M$. polymorpha. A multifactor approach allowed an assessment of the lability of foliar morphology in response to variation in resource supply, and of the separate and combined impacts of leaf morphology and resource levels on the arthropod food web. Two primary questions were addressed with this study. First, do changes in nutrient resources alter leaf thickness, the quantity of pubescence on leaves, or both? Previous studies of $M$. polymorpha suggest that, although leaf mass, per area individual is responsive to nutrient levels on young soils (Vitousek, 1998), leaf pubescence may be a fixed trait within trees (Cordell et al., 1998). Second, what are the separate and interactive effects of fertilisation and leaf pubescence on arthropod communities? Positive effects of fertilisation and negative effects of increasing pubescence on arthropod density and diversity were predicted, but interactive effects of these factors on species and community composition are virtually unexplored.

\section{Methods}

Study system and experimental design

This study was situated at 1280 m elevation on an 1881 pâhoehoe lava flow in the Upper Waiākea Forest Reserve, windward slope of Mauna Loa, Island of Hawai'i $\left(19.664^{\circ} \mathrm{N}, 155.284^{\circ} \mathrm{W}\right)$. As in many other native ecosystems throughout the archipelago (Dawson \& Stemmerman, 1999), M. polymorpha Gaudichaud-Beaupré (Myrtaceae) dominates this early successional wet forest $(\approx 4000 \mathrm{~mm}$ mean annual precipitation). Ferns [e.g. Dicranopteris linearis (Burm.) Underw. (Gleicheniaceae)], sedges [e.g. Machaerina angustifolia (Gaud.) T. Koyama (Cyperaeae)], 
and low shrubs [e.g. Coprosma ernodeoides A. Gray (Rubiaceae)] are also present (Gruner, 2004b).

The arthropod fauna associated with Metrosideros in the Hawaiian Islands is rich with species, but depauperate at higher functional and taxonomic levels because of biogeographic isolation (Howarth, 1990). Metrosideros polymorpha is attacked by multiple guilds of herbivorous insects, including several families of leaf-chewing Lepidopteran larvae, phloem- and xylem-feeding Heteroptera and Homoptera, gall-forming psyllids (Homoptera: Triozidae), and wood-boring coleopteran larvae (Swezey, 1954; Gagné, 1979; Stein, 1983). Invertebrate predators (e.g. Araneae, Heteroptera: Nabidae), hymenopteran parasitoids (e.g. Ichneumonidae, Bethyliidae, and Chalcidoidea), and litter processors, fungal grazers, and scavengers (e.g. Psocoptera, Isopoda, Collembola, some Coleoptera) are abundant within tree canopies.

This experiment took place as part of a larger study investigating the relative importance of birds and resources on the Metrosideros arthropod community (Gruner, 2004b). In August 1998, $3220 \times 20$ m plots were assigned fertilisation and avian insectivore exclusion treatments as crossed factors in a $2 \times 2$ randomised block design; the caged treatments were ignored in the present study. Sixteen plots were fertilised twice yearly from September 1998 to October 2000 with a broad spectrum of nutrients (Gruner, 2004b). Buffer strips, $10 \mathrm{~m}$ wide at minimum, separated all plots. Within each of eight blocks, there were two replicates of the fertilised treatment and two of the unfertilised control. Leaf morphology was investigated within each plot in a repeated-measures design.

\section{Pubescence and leaf mass per area}

An operational classification scale was devised to characterise hairiness of Metrosideros leaves, with slight modification to previous schemes (Kitayama et al., 1997). Trees were assigned to one of three categories: glabrous on both adaxial and abaxial surfaces $(G)$; thickly pubescent on stems and both leaf surfaces $(\mathrm{P})$; and pubescence appressed and intermediate (GP), found on abaxial, adaxial, or both surfaces, but where present, it could be rubbed off easily without damage to the leaf lamina. These classes correspond roughly to described varieties glaberrima, polymorpha, and incana respectively, but these names were not applied because of taxonomic uncertainties (Dawson \& Stemmerman, 1999; James et al., 2004). Although all $M$. polymorpha seedlings begin with glabrous leaves, they usually attain their final morphological state within 2 years (S. Cordell, pers. comm.). Multiple classes were not observed on any single tree in this study, although others have noted epicormic shoots with characteristics corresponding to different varieties (James et al., 2004).

Fertilisation on nearby young basaltic substrates decreased leaf mass per area (LMA) of M. polymorpha, although LMA typically does not change in response to fertilisation on older soils in the Hawaiian Islands
(Vitousek, 1998). LMA also increases with elevation (Geeske et al., 1994; Raich et al., 1997; Melcher et al., 2000), concomitant with increasing pubescence and with decreasing leaf area. LMA is related to leaf toughness (Wright \& Cannon, 2001), which is among the most important deterrents to leaf herbivory (Coley \& Barone, 1996).

The contribution of trichomes to LMA, and how this contribution might change with fertilisation and among leaf morphotypes, was evaluated. Within each plot, two whorls of the youngest fully expanded leaves were taken from two trees of the pubescent and intermediate morphological classes ( $P$ and GP). Two leaves were selected randomly from each of the whorls, for a total of eight leaves from each morphology - plot combination. Mass of leaf pubescence was determined in a procedure similar to previous work on M. polymorpha (Geeske et al., 1994; Cordell et al., 1998). Instead of using opposite leaves as paired samples, however, leaves were shaved with a razor on one side of the midrib of each leaf. A cork hole borer (disc area = $0.70 \mathrm{~cm}^{2}$ ) was used to sample tissue from each side. Leaf discs were dried to constant mass at $65^{\circ} \mathrm{C}$ and weighed to determine leaf mass and LMA $\left(\mathrm{g} \mathrm{m}^{-2}\right)$. The difference between unscraped and scraped mass from the same leaf was considered the mass of the pubescence.

\section{Arthropod sampling}

Arthropods were collected by clipping branches and foliage into heavy white plastic bags (Fretz, 2000; Gruner, $2004 \mathrm{~b})$. The terminal branchlets $(\approx 50 \mathrm{~cm})$ of twigs and foliage were clipped while avoiding reproductive structures (seeds, flowers). Many arthropod taxa in this system are reluctant to disperse from foliage even when disturbed (Gruner, pers. obs.). Nevertheless, extreme care was exercised in avoiding disturbance of branches and arthropods before branches were quickly bagged and then clipped.

On each sampling event, 12 samples were collected from a single block: one from G, GP, and P morphotypes on each of four plots. Blocks were randomly selected and sampled monthly from June to December of 1999, and in May and June 2000. Blocks therefore represented both temporal and spatial variation in arthropod communities. Haphazardly selected trees (10-20) were clipped for each sample in the morning hours, with the goal of sampling branchlets from as many different trees as possible while obtaining a roughly equivalent sample size (200-300 g dry foliage mass).

Foliage was transported to the laboratory at Hawai' $i$ Volcanoes National Park for immediate processing. Foliage was shaken and beaten onto a white cloth and arthropods were collected with an aspirator and stored in $70 \%$ ethanol. Branches were shaken and the detrital remainder sifted until no additional arthropods were observed. Foliage was separated from woody material, oven-dried to constant mass, and both components weighed to milligram precision. Arthropod abundance 
and biomass are reported per 100 g dry foliage mass ('load', sensu Root, 1973).

\section{Analysis of arthropod samples}

All arthropods collected were recorded, measured for length to the nearest millimetre, and identified to species or assigned to morphospecies based on morphological evidence and advice of taxonomic experts. Regressions of body length to dry mass were used to estimate biomass (Gruner, 2003). Specimens data were managed using the biodiversity collections database software, Biota (Colwell, 1997). Bulk material and voucher specimens were deposited at the B. P. Bishop Museum, Honolulu.

Arthropods were assigned to one of four trophic levels carnivores, detritivores, herbivores, and tourists - based on personal observation, literature review, and communication with systematists (see Appendix). Carnivores included various predatory arthropods (e.g. Araneae, some Heteroptera and Coleoptera) and hymenopteran parasitoids (Ichneumonidae, Bethyliidae, and Chalcidoidea); detritivores included saprophagous arthropods and grazers of litter, fungi, and microbes (e.g. Psocoptera, Isopoda, Collembola, some Coleoptera); and herbivores consisted of sap-feeders (Heteroptera and Homoptera), gall-forming psyllids (Homoptera: Triozidae, mostly free-living adults), and foliage-chewing Lepidoptera. Tourists included species known to be incidental or non-feeding on Metrosideros (e.g. adult moths), or with unknown or highly omnivorous feeding habits. Over 100 arthropod species have been recorded from M. polymorpha at the site (Gruner, 2004a, 2004b).

Several indices were used to represent species diversity. To account for differences in the sizes of samples, species density was calculated by dividing species number by the mass of the foliage in a given sample. Individual-based rarefaction was not used because of low abundance counts in several samples. Instead, the Shannon diversity index $\left(H^{\prime}\right)$ was used a measure of relative diversity, to control for total arthropod abundance, and to incorporate evenness (Magurran, 1988). Shannon $H^{\prime}$ was computed for individual collections using PRIMER software (Clarke, 2001).

\section{Statistical analyses}

The design of this study (ignoring the bird exclusion treatments) was equivalent to a repeated-measures design. The block term accounted for temporal and spatial environmental heterogeneity. Fertilisation (fixed) and block (random) and their interaction were between-subject effects; the random subject factor, plots, was nested within these main effects; and morphology and all its two-way interactions were within-subject effects. The three-way interaction (fertilisation $\times$ morphology $\times$ block) was dropped from the model after determining it was uniformly non-significant. Models were analysed with type III sums of squares in SAS PROC MIXED (SAS, 2001), with d.f. for error mean squares of random terms estimated by the Satterthwaite approximation. Tukey-Kramer tests were used for comparisons of morphology main effects only (joint $\alpha=0.05$ ).

Natural log transformation was sufficient to meet assumptions of normality and homoscedasticity for pubescence mass, arthropod density and biomass, but was not necessary for species density, relative diversity, or LMA. Density and biomass of the six most abundant taxonomic orders (Acari, Araneae, Collembola, Heteroptera, Homoptera, and Psocoptera) were analysed, and the orders not sufficiently abundant or widespread for separate analyses were lumped into single variables (Coleoptera, Diptera, Hymenoptera, Isopoda, Lepidoptera, Neuroptera, and Thysanoptera). Separate models were run for arthropod variables aggregated into trophic levels: carnivores, herbivores, and detritivores. Untransformed means $( \pm 1 \mathrm{SE})$ are reported.

Several methods based on matrices of ecological distances (dissimilarity) between samples were used to analyse the effects of fertilisation and leaf morphology on arthropod community composition. These methods recognise species identities and treat the community as a multivariate entity. Prior to calculating the distance matrices, abundances were $\log _{10}(X+1)$ transformed to reduce the influence of a few highly abundant species. Transformed abundances were then relativised by dividing by their sum for each sample, to reduce the effect of differences among samples in total abundance and therefore to emphasise differences in relative proportions of taxa. Euclidean distances ('distance between species profiles', Legendre \& Gallagher, 2001) then were calculated; qualitatively similar results were obtained using several non-Euclidean measures (e.g. Bray-Curtis distance).

Hypotheses for change in community composition were tested with non-parametric multivariate analysis of variance (NPMAnOva; Anderson, 2001; McArdle \& Anderson, 2001). In effect, NPMANOVA partitions the distance matrices into parts attributable to the terms in a general linear model, generating pseudo- $F$ statistics for each term; these are tested by comparing them to the distributions of values produced when the data are randomly permuted according to the null hypothesis appropriate for the given term. Because of the multifactor design of this study, the DISTLM (Anderson, 2000) implementation of NPMANOVA was used. For each test, 4999 permutations of the raw data were used, in units defined by the 'error' term of the corresponding pseudo- $F$ ratio. Data were analysed for all trophic levels, and both with and without Salina celebensis (Schaeffer) (Collembola), which alone accounted for almost $70 \%$ of individuals. Metric multidimensional scaling (principal coordinates analysis, PCO; Legendre \& Legendre, 1998) was used to reduce the dimensionality of the species data to orthogonal axes and further explore relationships to treatments (this analysis using Euclidean distances is equivalent to principal components analysis, Legendre \& Legendre, 1998). 
Redundancy analysis (RDA; Legendre \& Legendre, 1998) was used to constrain these ordinations by original experimental treatments, and to relate these axes back to individual species. RDA was conducted using the 'vegan' package, version 1.6-4 (http://cc.oulu.fi/ jarioksa/), in the R statistical language, version 1.9.1 (http://www.r-project.org). Partial redundancy analysis demonstrated that the fertilisation factor explained little variation beyond that explained by morphotype class alone; thus, canonical redundancy analysis proceeded on this single factor with three levels, ignoring blocks. RDA results were visualised in a two-dimensional biplot with the strongest species vectors, calculated as the sum of the absolute values of species loadings from both RDA axes, plotted in relation to sample scores and centroids for morphology classes. Sample scores in biplots were weighted sums of species scores, using RDA scaling 1 (site scores scaled proportional to axis eigenvalues and species unscaled), which preserves distances among samples.

\section{Results}

\section{Foliar characteristics}

Fertilisation strongly decreased LMA in unscraped leaf discs (Fig. 1; $F_{1,7}=225.86, P<0.0001$ ), and LMA also was greater in pubescent $(\mathrm{P})$ leaves than intermediate (GP) forms $\left(F_{1,7}=21.60, \quad P=0.002\right)$. Leaf scraping allowed separation of these two effects into their components: mass of leaf hairs was responsible for the significant difference in LMA between $\mathrm{P}$ and GP $\left(F_{1,7}=82.74\right.$, $P<0.0001)$, and fertilisation decreased mass per area of leaf tissue exclusive of pubescence $\left(F_{1,7}=164.01\right.$, $P<0.0001)$. Fertilisation did not change pubescence, and none of 88 marked trees changed morphology class over 33 months.

Average foliage mass clipped in arthropod collections was similar among morphologies (overall mean, $\left.244.1 \mathrm{~g}, \pm 4.4 \mathrm{SE} ; F_{2,14}=1.59, P=0.240\right)$; however, the biomass of foliage collected from unfertilised plots was slightly higher than from fertilised plots (fertilised $234.6 \mathrm{~g} \pm 6.0 \mathrm{SE}$, unfertilised $256.0 \mathrm{~g} \pm 6.1 ; F_{1,7}=10.60$, $P=0.014)$. This did not have marked effects on density or biomass results, as absolute abundance and biomass showed similar patterns as the loads standardised to foliage biomass of collections. To maintain consistency with other studies (Fretz, 2000; Gruner, 2004b), results based on loads are reported.

\section{Abundance and biomass}

A total of 8840 individuals in 99 species and morphospecies from 13 arthropod orders were collected from M. polymorpha clippings in this study (see Appendix).

The effects of fertilisation and leaf morphology on density and biomass differed among arthropod orders, but in

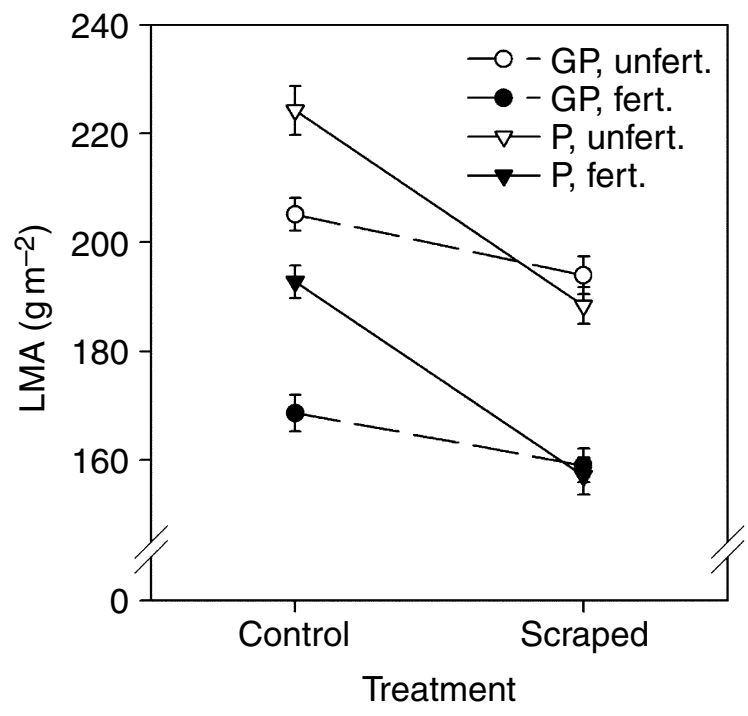

Fig. 1. Means $( \pm 1 \mathrm{SE})$ of LMA $\left(\mathrm{g} \mathrm{m}^{-2}\right)$ of leaf discs from pubescent (P) and intermediate (GP) foliar morphologies in fertilised (fert.) and unfertilised (unfert.) plots. Discs were either un-manipulated or scraped of all leaf hairs.

no case was there statistically significant interaction between them (Fig. 2; Table 1). Density and biomass of Acari were higher on intermediate morphologies (Fig. 2a,b) although these effects varied among blocks. Spiders were more abundant on fertilised plots, irrespective of leaf form (Fig. 2c), but did not differ in biomass (Fig. 2d). Collembola density and biomass, dominated by a single species (S. celebensis $>99 \%$ of all Collembola individuals), increased strongly with fertilisation, decreased with increasing leaf pubescence, and varied across blocks (Fig. 2e,f). Fertilisation increased the density but not biomass of both Heteroptera and Homoptera, and Heteroptera were more abundant on increasingly pubescent foliage (Fig. 2g,j); Heteroptera density also showed a significant fertilisation $\times$ block interaction (Table 1 ). Psocoptera density and biomass did not respond to fertilisation, but both were significantly elevated on pubescent forms relative to the glabrous and intermediate morphologies (Fig. 2k,1). The aggregate grouping from less abundant orders did not change with treatments (Fig. 2m,n).

Fertilisation increased the density of all trophic levels on M. polymorpha (Table 2, Fig. 3). Detritivores, dominated by Collembola (Fig. 2e,f), were the most abundant trophic group (Fig. 3c). Highly significant effects of fertilisation, leaf morphology, and blocks on detritivore density drove the same suite of results for all arthropods in aggregate (Fig. 3a,b). Fertilisation effects on herbivore density varied significantly across blocks (Table 2). There were no significant effects of morphology or fertilisation on trophic-level biomass (Fig. 3), except for significant fertilisation $\times$ block interactions for herbivore, detritivore, and total arthropod biomass (Table 2). Detritivore biomass varied across blocks, and the plot term was significant for carnivore 
Fig. 2. Means ( $\pm 1 \mathrm{SE})$ of density and biomass of arthropod taxonomic orders, as a function of dry foliage biomass, on glabrous $(\mathrm{G})$, intermediate (GP), and pubescent (P) foliar morphologies in fertilised (fert.; filled bars) and unfertilised (control; unfilled) plots. The 'all others' $(\mathrm{m}, \mathrm{n})$ category combines less abundant orders (Coleoptera, Diptera, Hymenoptera, Isopoda, Lepidoptera, Neuroptera, and Thysanoptera). Lowercase letters denote significant differences in the leaf morphology main effect tested by the TukeyKramer test (adjusted $\alpha=0.05$ ); insets ( $F$, fertilised; NF, not fertilised) indicate the direction of significant $F$-ratios from GLMs.
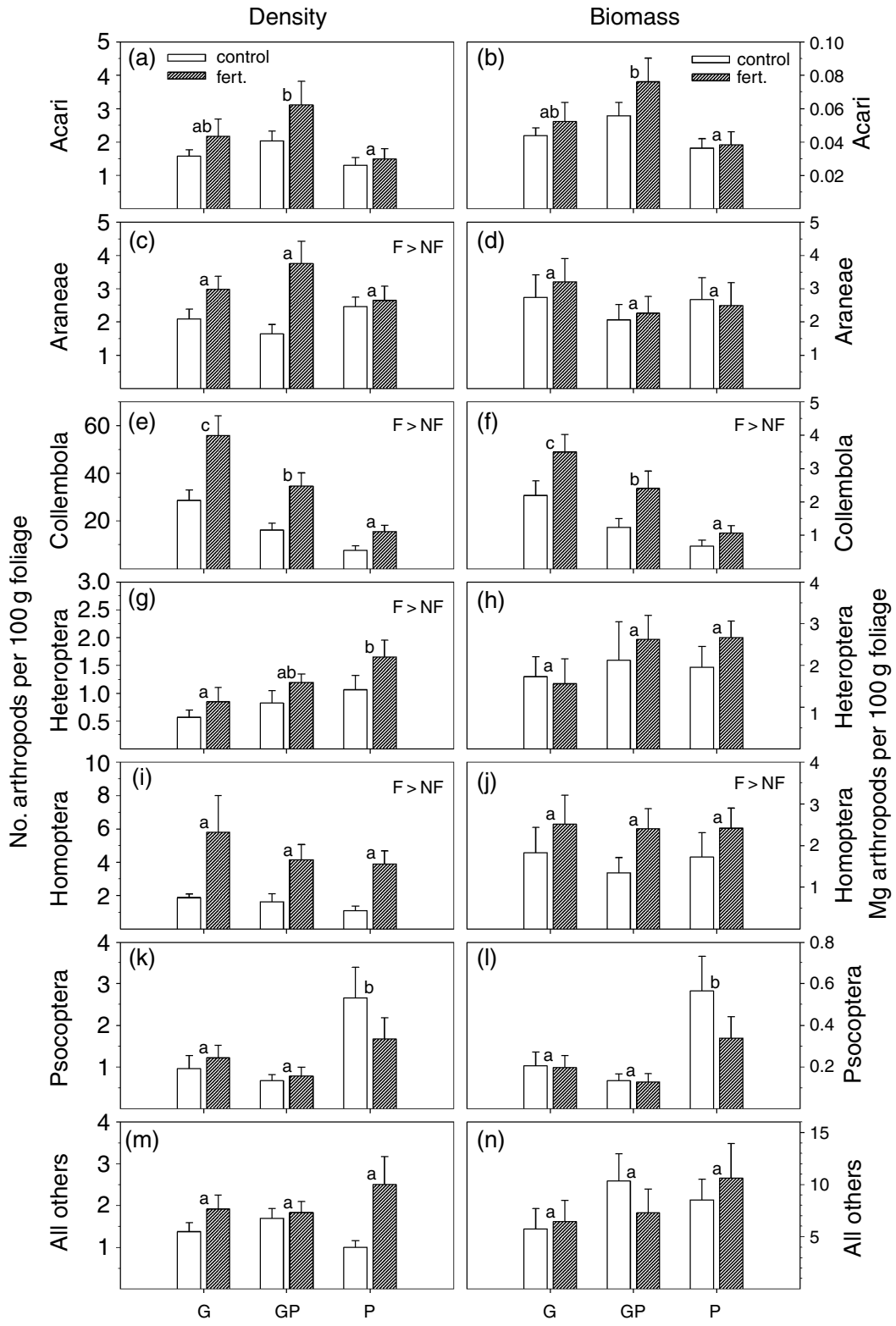

(n)

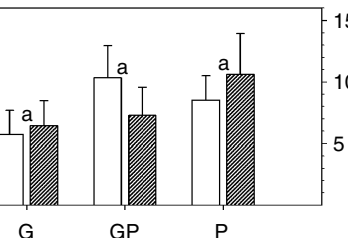

$=15$ biomass. Although the block factor was significant in tests with various arthropod variables, there were no discernible temporal trends. Fertilisation led to higher arthropod numbers relative to unfertilised plots on most sampling dates and across morphological classes. This result was more equivocal for arthropod biomass and for the pubescent morphology.

\section{Species diversity}

Fertilisation increased species density (number of species per unit foliage) for all trophic levels (Fig. 4, Table 3). This fertilisation effect also varied significantly across blocks for all trophic levels except detritivores. There were no significant effects of leaf morphology on species density, other than the morphology $\times$ block interaction for carnivores (Table 3). Behaviour of the Shannon $H^{\prime}$ diversity index was distinct from species density results (Fig. 4, Table 3). Relative diversity for herbivores was higher with fertilisation (Fig. 4f). However, the fertiliser effect varied across blocks for both carnivores and herbivores, and all arthropods in aggregate varied across blocks and plots (Table 3). Detritivore diversity increased with increasing pubescence level (Fig. 4d), a result paralleled by arthropod totals (Fig. 4b). Morphology effects also interacted with block effects for all arthropods in aggregate. 


\section{Species composition}

NP MANOVA showed no effect of fertilisation, nor any interaction involving fertilisation on the total community or any of the trophic level assemblages. However, leaf morphology strongly influenced the composition of the entire community (pseudo- $F_{2,14}=3.808, P=0.0002$ ), the detritivorous assemblage (pseudo- $F_{2,14}=7.950$, $P=0.0002)$, and there was a suggestion of an effect on herbivores (pseudo- $F_{2,14}=2.426, P=0.060$ ). When the most abundant collembolan species ( $S$. celebensis) was removed from the detritivorous and aggregate assemblages, leaf morphology effects remained significant, although less strongly so (total: pseudo- $F_{2,14}=2.753, P=0.007$; detritivores: pseudo- $\left.F_{2,14}=3.770, P=0.044\right)$. The block term was strongly significant for all trophic levels (all $P$-values $<0.001)$. Blocks also interacted significantly with leaf morphology in the community overall, but not within trophic levels [significant morphology $\times$ block interaction, total: pseudo- $F_{14,46}=1.194, P=0.038$; total (no Salina): pseudo- $\left.F_{14,46}=1.169, P=0.042\right]$. Visual inspection of scatterplots of blocks against time or spatial proximity did not reveal clear seasonality or directional temporal trends (i.e. increasing fertilisation effect) in arthropod response variables or PCO axes.

Constrained ordination (RDA) showed little overlap between communities from pubescent and glabrous trees; samples from GP trees mostly fell between the two extreme morphologies, fairly distinct from the cluster of P samples but overlapping substantially with the G samples (Fig. 5a). Samples from pubescent trees were characterised by the high abundances of the detritivorous psocid Kilauella sp. 3, the herbivorous mirid Sarona adonias Kirkaldy, and the pit gall-forming Kuwayama sp. 1, and by low abundances of the cicadellid Nesophrosyne giffardi Kirkaldy and the collembolan S. celebensis (Fig. 5b; Appendix). Conversely, high abundances of $S$. celebensis, N. giffardi, and the psocid Valenzuela badiostigma (Okamoto), along with low abundances of Kuwayama sp. 1, S. adonias, and the isopod Porcellio scaber Latreille typified communities on glabrous trees. Intermediate pubescence (GP morphology) was correlated with low abundance of Kilauella sp. 3 and high abundances of three predatory arachnids: the spiders Tetragnatha acuta Gillespie and Misumenops anguliventris (Simon), and the mite Anystidae g. sp. 1.

\section{Discussion}

Is foliar pubescence ecologically labile?

In this highly nutrient-limited environment, LMA decreased but trichome mass did not change in response to the experimental fertilisations (Fig. 1). Previous studies of $M$. polymorpha showed that morphological traits, such as trichome structure and density, have a genetic basis, whereas ecophysiological behaviour and anatomical 
Table 2. $P$-values from GLMs of density and biomass of arthropod trophic groups. Response variables were $\log _{\mathrm{e}}$ transformed prior to analysis. Italicised sources represent random terms. Significant $F$-values are indicated with boldface.

\begin{tabular}{|c|c|c|c|c|c|c|c|c|c|}
\hline \multirow[b]{2}{*}{ Source } & \multirow[b]{2}{*}{ d.f. ${ }^{a}$} & \multicolumn{4}{|c|}{ Density load } & \multicolumn{4}{|c|}{ Biomass load } \\
\hline & & All & Carnivores & Herbivores & Detritivores & All & Carnivores & Herbivores & Detritivores \\
\hline Fertilisation $(\mathrm{F})$ & 1,7 & $<0.001$ & 0.010 & 0.008 & 0.002 & 0.116 & 0.462 & 0.143 & 0.333 \\
\hline Block (B) & $7,{ }^{b}$ & $<0.001$ & 0.330 & 0.110 & 0.005 & 0.083 & 0.191 & 0.722 & 0.011 \\
\hline $\mathrm{F} \times B$ & 7,16 & 0.384 & 0.208 & 0.004 & 0.158 & 0.048 & 0.928 & 0.005 & 0.013 \\
\hline $\operatorname{Plot}(F B)$ & 16,46 & 0.113 & 0.807 & 0.855 & 0.265 & 0.727 & 0.034 & 0.984 & 0.883 \\
\hline Morphology (M) & 2,14 & $<\mathbf{0 . 0 0 1}$ & 0.982 & 0.833 & $<0.001$ & 0.981 & 0.679 & 0.470 & 0.864 \\
\hline $\mathrm{M} \times \mathrm{F}$ & 2,46 & 0.313 & 0.141 & 0.302 & 0.488 & 0.859 & 0.756 & 0.709 & 0.298 \\
\hline $\mathrm{M} \times B$ & 14,46 & 0.235 & 0.277 & 0.255 & 0.580 & 0.570 & 0.088 & 0.403 & 0.248 \\
\hline
\end{tabular}

${ }^{\mathrm{a}}$ Numerator, denominator d.f.

${ }^{\mathrm{b}}$ Denominator d.f. variable; estimated by Satterthwaite approximation.

features, such as LMA, were inducible by environmental factors in a common garden setting (Cordell et al., 1998). This independence of morphological and physiological features has been documented in other plant species (Roy et al., 1999; Forkner \& Hare, 2000). However, increased trichome density may be induced by heavy herbivore defoliation or by intense disturbance events, such as hurricanes (Pullin \& Gilbert, 1989; Dalin \& Björkman, 2003; Spiller \& Agrawal, 2003) - this alternative has not been tested in the present system.

\section{Community responses to fertilisation}

Increased densities in response to fertilisation were observed in four arthropod orders and all trophic levels
(Figs 2 and 3; Tables 1 and 2). Reviews of population and community responses to fertilisation have shown positive effects on herbivorous arthropod abundance in many studies (Waring \& Cobb, 1992; Kytö et al., 1996). This response is attributed generally to increased resource quantity, increased soluble plant tissue $\mathrm{N}$ and dissolved amino acids, or reduced allocation to carbon-based chemical or structural defence (Mattson, 1980; Strong et al., 1984; Keinanen et al., 1999; Ritchie, 2000). In this study, fertilisation decreased LMA (Fig. 1), which is positively related to leaf toughness (Wright \& Cannon, 2001), an important deterrent to leaf herbivory (Coley \& Barone, 1996). Detritivores also stand to benefit from these changes, as higher nutrient concentrations decrease lignin concentrations and increase the decomposability of Metrosideros litter (Vitousek, 1998; Hobbie, 2000). Plant nutrient status
Fig. 3. Means ( $\pm 1 \mathrm{SE}$ ) of arthropod trophic level density and biomass, as a function of dry foliage biomass, on glabrous $(\mathrm{G})$, intermediate (GP), and pubescent (P) foliar morphologies in fertilised (fert.; filled bars) and unfertilised (control; unfilled) plots. Lowercase letters denote significant differences in the leaf morphology main effect tested by the Tukey-Kramer test (adjusted $\alpha=0.05$ ); insets ( $F$, fertilised, NF; not fertilised) indicate the direction of significant $F$-ratios from GLMs.

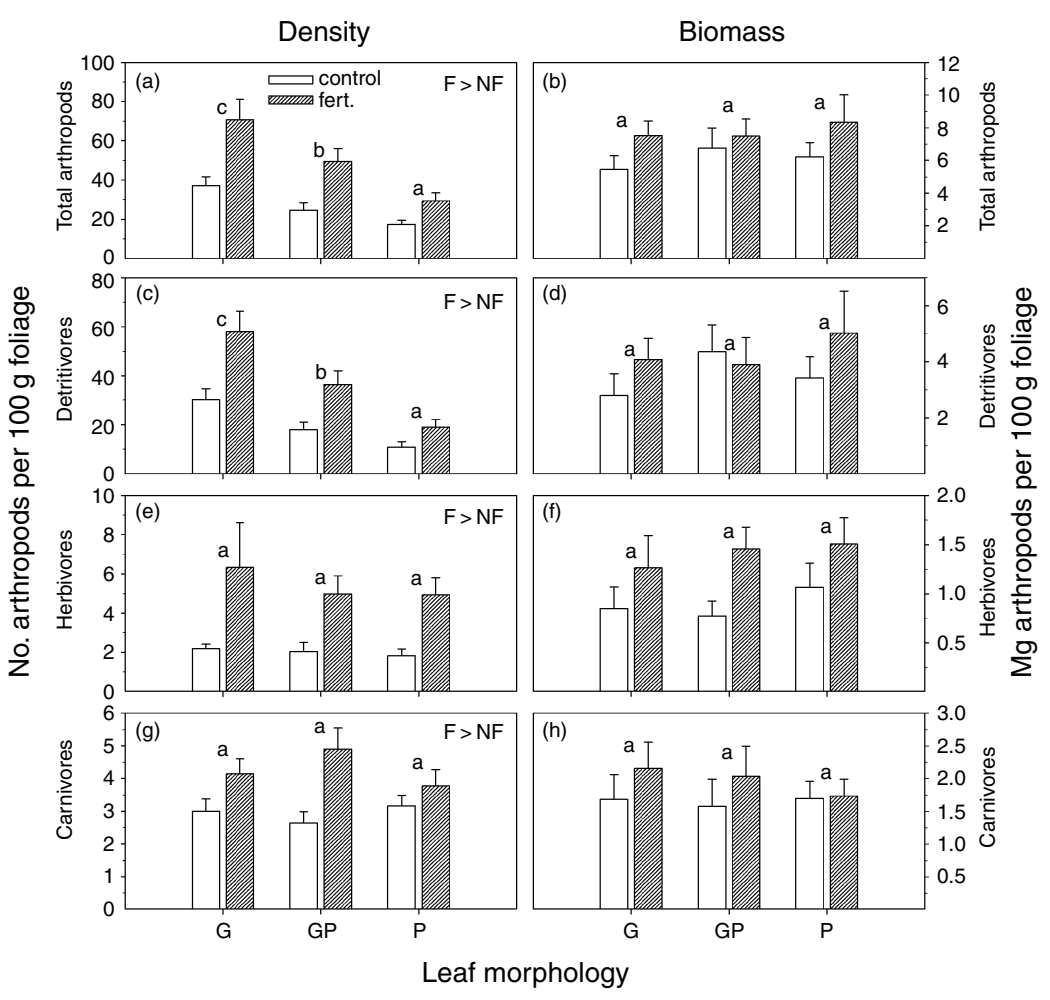



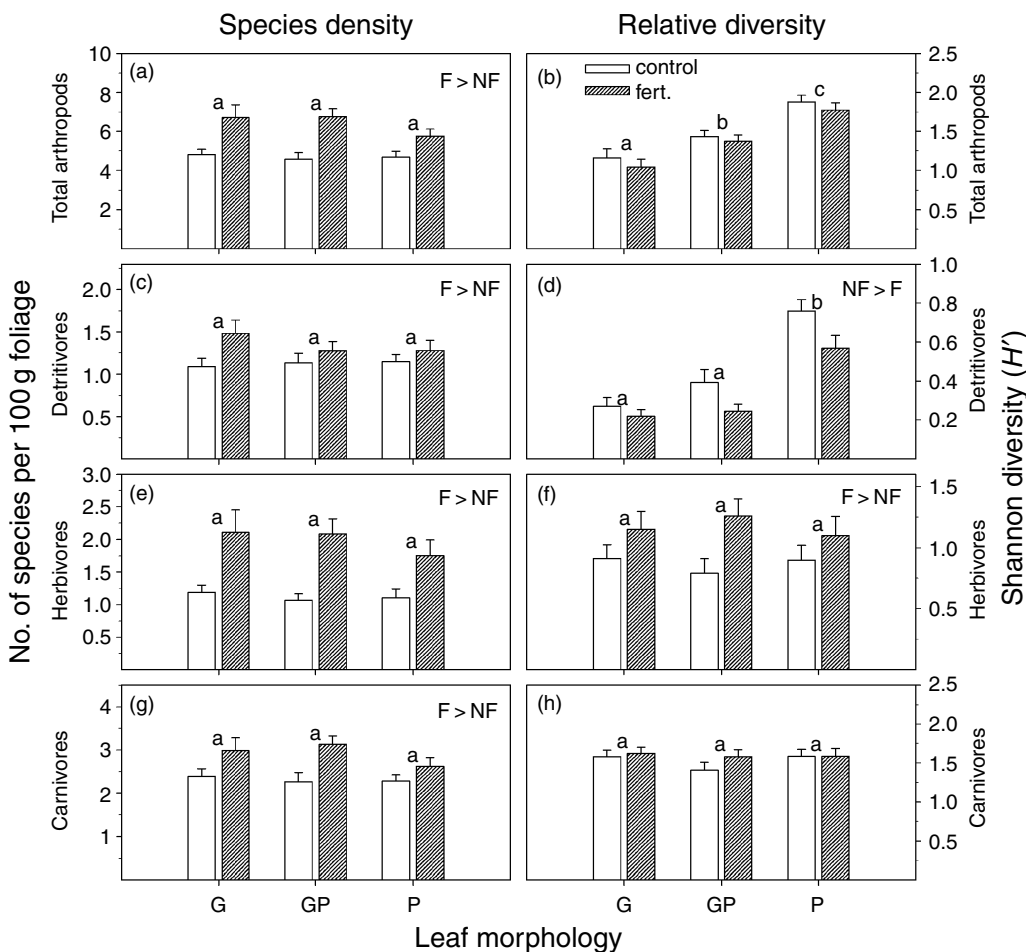

Fig. 4. Means ( $\pm 1 \mathrm{SE})$ of arthropod trophic level species density (richness per $100 \mathrm{~g}$ foliage) and relative diversity (Shannon $H^{\prime}$ ) on glabrous $(\mathrm{G})$, pubescent $(\mathrm{P})$, and intermediate (GP) foliar morphologies in fertilised (fert.; filled bars) and unfertilised (control; unfilled) plots. Results for Fisher's $\alpha$ were similar to Shannon $H^{\prime}$, and are not shown. Lowercase letters denote significant differences in the leaf morphology main effect tested by the Tukey-Kramer test (adjusted $\alpha=0.05$ ); insets ( $\mathrm{F}$, fertilised; NF, not fertilised) indicate the direction of significant $F$-ratios from GLMs. can cascade up to natural enemies (Forkner \& Hunter, 2000; Denno et al., 2002), which may suffer even more pervasive nutrient limitation (Fagan et al., 2002). Invertebrate predators, particularly spiders, may respond also to increased structural heterogeneity created in fertilised plots (Langellotto \& Denno, 2004). Herbivore and detritivore biomass also increased in some fertilised blocks, but this effect was weak and variable (Table 2), consistent with a related study that showed smaller individuals dominate the response to nutrient enrichment (Gruner, 2004b).

Responses of community species richness or diversity in other studies have been more variable and equivocal than abundances (Hurd \& Wolf, 1974; Kirchner, 1977; Sedlacek et al., 1988; Haddad et al., 2000). Discrepancies in the qualitative responses of diversity across systems may be biologically based and system specific, or might vary according to differences in spatial scale (Whittaker \& Heegaard, 2003), trophic or taxonomic focus (Haddad et al., 2000), diversity metric or standardisations employed (McCabe \& Gotelli, 2000), or experimental time frame (Haddad et al., 2000). For example, long-term fertilisations frequently decrease plant richness or otherwise alter species composition concomitant with increasing productivity (Siemann, 1998; Waide et al., 1999; Haddad et al., 2000). Potential confounding from plant community compositional changes with fertilisation was avoided by isolating the single host, the dominant tree species M. polymorpha. Concerns about scale were addressed by sampling periodically over a 1-year time frame, and by reference to a study examining arthropod responses to a productivity gradient across the Hawaiian archipelago (Gruner, 2004c). Moreover, all trophic levels and taxonomic orders were

Table 3. $P$-values from GLMs for species density and Shannon $H^{\prime}$ of arthropod trophic levels. Italicised sources represent random terms. Significant $F$-values are indicated with boldface.

\begin{tabular}{|c|c|c|c|c|c|c|c|c|c|}
\hline \multirow[b]{2}{*}{ Source } & \multirow[b]{2}{*}{ d.f. ${ }^{\mathrm{a}}$} & \multicolumn{4}{|c|}{ Species density } & \multicolumn{4}{|c|}{ Shannon $H^{\prime}$} \\
\hline & & All & Carnivores & Herbivores & Detritivores & All & Carnivores & Herbivores & Detritivores \\
\hline Fertilisation (F) & 1,7 & 0.009 & 0.038 & 0.024 & 0.002 & 0.264 & 0.445 & 0.044 & 0.042 \\
\hline Block (B) & $7,{ }^{b}$ & 0.321 & 0.543 & 0.461 & 0.437 & 0.046 & 0.185 & 0.262 & 0.361 \\
\hline $\mathrm{F} \times B$ & 7,16 & 0.013 & 0.027 & 0.001 & 0.953 & 0.309 & 0.007 & 0.048 & 0.325 \\
\hline $\operatorname{Plot}(F B)$ & 16,46 & 0.627 & 0.636 & 0.694 & 0.497 & 0.026 & 0.960 & 0.864 & 0.063 \\
\hline Morphology (M) & 2,14 & 0.407 & 0.574 & 0.490 & 0.705 & $<0.0001$ & 0.439 & 0.973 & $<0.0001$ \\
\hline $\mathrm{M} \times \mathrm{F}$ & 2,46 & 0.230 & 0.342 & 0.486 & 0.418 & 0.847 & 0.519 & 0.494 & 0.247 \\
\hline $\mathrm{M} \times B$ & 14,46 & 0.116 & 0.027 & 0.210 & 0.541 & 0.004 & 0.258 & 0.175 & 0.169 \\
\hline
\end{tabular}

${ }^{\mathrm{a}}$ Numerator, denominator d.f.

${ }^{\mathrm{b}}$ Denominator d.f. variable; estimated by Satterthwaite approximation. 


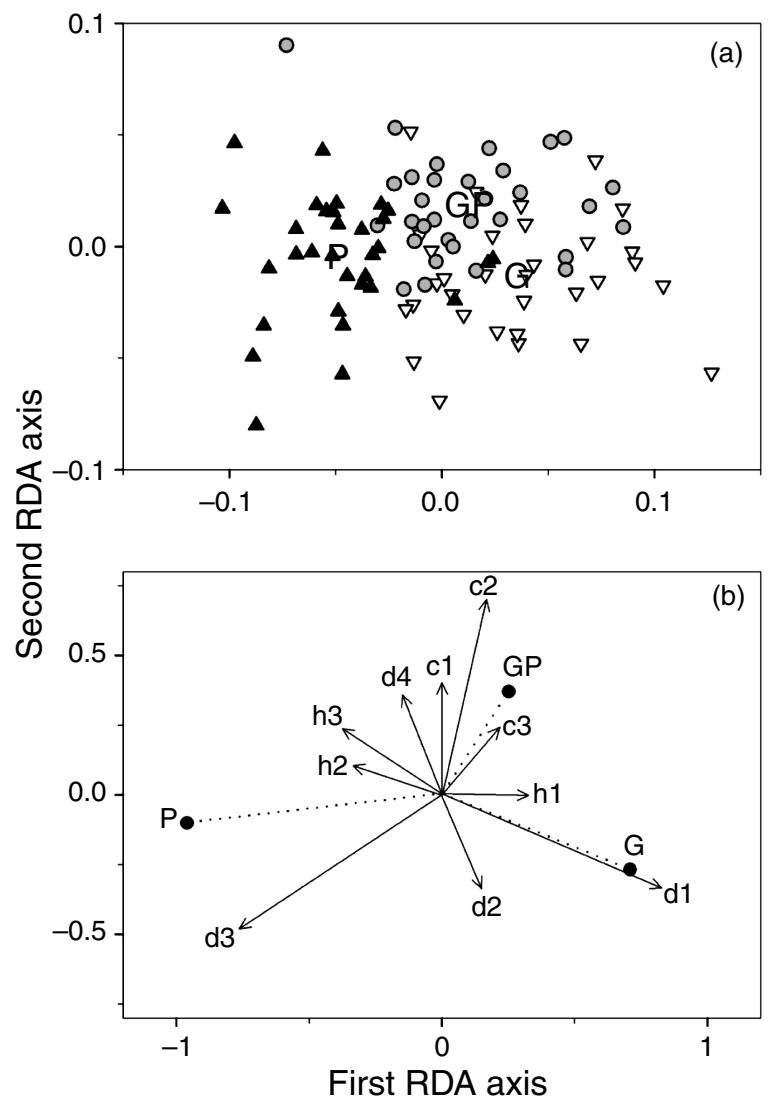

Fig. 5. Redundancy analysis of species abundances in relation to leaf pubescence type. The two RDA axes represent the principal components of the multivariate (all 99 species) means for the three leaf morphologies. (a) Constrained ordination of the 96 samples, coded by leaf morphology. Empty triangles, glabrous $(\mathrm{G})$; grey circles, intermediate (GP); filled triangles, pubescent $(\mathrm{P})$; letters indicate centroids. (b) Biplot representing correlations of leaf morphologies (labelled dashed lines) and species (arrows; 10 most important only): Salina celebensis, Valenzuela badiostigma, Kilauella sp. 3, Porcellio scaber (detritivores, d1-d4); Nesophrosyne giffardi, Kuwayama sp. 1, Sarona adonias (herbivores, h1-h3); Tetragnatha acuta, Misumenops anguliventris, Anystidae g. sp. 1 (carnivores c1-c3; see Appendix for species information). Note the differing scales of axes among plots.

examined to provide a broad understanding of communitywide responses, and multiple diversity metrics were compared within these groups.

Species density of all trophic levels increased with fertilisation (Fig. 4), but this result may be attributable to increased abundances. Using the Shannon index to account for relative abundance, herbivore diversity alone was elevated with fertilisation (Fig. 4d, Table 3), whereas the diversity of detritivores actually decreased (Fig. 4f, Table 3). Because fertilisation increased herbivore abundance but did not change equitability (Pielou's $J^{\prime}$ overall mean $\pm \mathrm{SE}$ : $0.89 \pm 0.01$, all $F$-tests NS), higher herbivore diversity may be an indirect result of rare species becoming abundant enough to persist locally ('consumer rarity hypothesis' sensu
Siemann, 1998; 'more individuals hypothesis' sensu Srivastava \& Lawton, 1998). In contrast, detritivore diversity declined with fertilisation due to increasing dominance of a single species, $S$. celebensis, which was by far the most abundant animal on trees $(>99 \%$ of Collembola individuals in Fig. 2e). Somewhat surprisingly, despite these differing effects on abundance and diversity of different trophic groups, analysis of overall community composition (NPMANOVA) revealed no consistent effect of fertilisation. It may be that temporal or spatial variation among blocks, or the relatively short duration of the fertilisation manipulation $(<2$ years $)$, obscured a modest fertilisation effect.

\section{Community responses to foliar pubescence}

Arthropod responses to $M$. polymorpha pubescence classes varied with, and within, taxonomic orders and trophic levels (Figs 2, 3 and 4). Although previous studies have shown that trichomes can interfere with the foraging behaviour of insect predators or parasitoids (Van Lenteren et al., 1995; Eisner et al., 1998), natural enemies did not vary with leaf pubescence on $M$. polymorpha (Figs 3 and 4). Herbivore variables also were unchanged overall across leaf pubescence levels, despite evidence for associations of individual species (Fig. 5b) and observations that oviposition or damage by several species were more frequent on glabrous morphologies at this and nearby sites (Lee, 1981; Alyokhin et al., 2004; D. S. Gruner, unpublished data). Many of the herbivorous lineages that utilise Metrosideros in this community are internal feeders, predominantly budmining Lepidoptera and gall-forming psyllids. Cornell (1989) hypothesised that gall-formers, leaf-miners, and other endophagous insects can avoid leaf defences, and empirical studies have shown that some gall-formers can manipulate the mechanical or chemical defences of their host plants (Hartley, 1998; Nyman \& Julkunen-Tiitto, 2000). The abundance of internal-feeding species on manzanita (Arctostaphylos spp. Ericaceae) was not influenced by length, density or glandularity of trichomes (Andres \& Connor, 2003). Demographic studies on developing Metrosideros leaf cohorts may more effectively evaluate this prediction for herbivore species in their most actively feeding juvenile stages (D. S. Gruner, unpublished data).

Detritivores as a group increased in abundance (Fig. 3c) but decreased in diversity (Fig. 4d) on more glabrous morphologies. Much of the increase in density again can be attributed to $S$. celebensis; nevertheless, deletion of $S$. celebensis did not erase the significant influence of leaf morphology on detritivore community composition (NPMANOva pseudo- $F_{2,14}=3.770, \quad P=0.044$ ). Higher abundance of detritivores on glabrous forms could arise from several mechanisms. Although nitrogen concentrations did not differ among morphologies (one-way ANOVA from unfertilised trees, $F_{2,30}=1.42, \quad P=0.257$, see Methods in Gruner, 2004b), pubescent leaf litter may be less palatable because of higher levels of cellulose, lignins, or condensed tannins. Alternatively, detritivores may 
respond indirectly to herbivory by phytophagous insects. In particular, stem galls (Trioza hawaiiensis Crawford) occurred in higher frequency among glabrous morphotypes, less so on intermediate forms, and never on pubescent morphologies at this site (D. S. Gruner, unpublished data). These galls often sever and kill stems and leaves with swollen gall tissue. This can provide a direct input of dead organic matter remaining attached to the plant or otherwise suspended in the canopy, and may encourage fungal growth for grazers like Collembola (D. Gruner, pers. obs.). On Salix, insect stem galls increased the growth of lateral shoots, which were then less tough and had higher nitrogen and water contents (Nakamura et al., 2003). In addition to increased food resources, evacuated galls provide structural heterogeneity on Metrosideros, and Collembola and Psocoptera were observed foraging or residing within excavated gall tissues on leaves or stems.

Arthropod response was heterogeneous among orders, with species of Psocoptera (Kilauella sp. 3), Heteroptera (Sarona adonias), and Homoptera (Kuwayama sp. 1) in highest numbers on the most pubescent leaves, and a predatory anystid mite most abundant on intermediate forms (Figs 2 and 5b). Some small arthropods also may benefit from habitat heterogeneity offered by trichomes. On bean plants, predatory mites preferentially selected artificial pubescence as habitat structure and were more abundant on leaves with trichomes (Roda et al., 2001). Diametrically opposed responses of different phytophagous taxa have been reported in response to glandular trichomes of Datura wrightii (van Dam \& Hare, 1998), and across guilds on Arbutus xalapensis (Ezcurra et al., 1987). Psocoptera distributions could reflect negative competitive outcomes with abundant Collembola, as species from both groups scavenge dead organic matter and graze lichens, fungi, and algae (Thornton, 1985; Christiansen \& Bellinger, 1992). Alternatively, there may be differences in bark structure, tree architecture, or distribution and abundance of microepiphytes or endophytic fungi correlated with foliar pubescence. Pubescent leaves may have a longer leaf lifespan (Cordell et al., 2001; D. S. Gruner, unpublished data), which would favour the development of psyllids that induce galls later in leaf ontogeny (i.e. leaf pit galls, Kuwayama sp. 1; Fig. 5b), and may favour inquiline arthropods that utilise these evacuated shelters.

\section{Conclusions}

This study demonstrates the bottom-up influence of $M$. polymorpha foliar pubescence on arthropod communities. Although the functional significance of trichomes in $M$. polymorpha is unclear, distributional gradients of morphological forms suggest that pubescence is linked to resources or abiotic factors (Corn \& Hiesey, 1973; Geeske et al., 1994; Cordell et al., 1998; Melcher et al., 2000). However, responses of aggregate arthropod variables to pubescence generally acted independently of resource availability, and effects were more pronounced on the relative diversity and species composition of the community than observed with fertilisation. Fertilisation increased the numbers and species densities of most arthropod groups; in contrast, leaf morphology had contrasting positive and negative effects on restricted taxonomic groups within trophic levels. Thus, qualitative differences in trichome density and leaf structure appeared to be more important than resource quantity for Metrosideros arthropod community composition. Moreover, the effects of such leaf traits vary greatly among species, depending on details of their natural history, and may be difficult to predict with much specificity. Given the diversity of effects, and the abundance of detritivores in this forest ecosystem (Gruner, 2004b), leaf morphology may have implications equal or greater in importance for decomposers and litter processors than for herbivores, suggesting that trichomes of $M$. polymorpha may be tied functionally to the cycling of nutrients and biomass in this nutrient limited ecosystem.

\section{Acknowledgements}

We thank the Division of Forestry and Wildlife, State of Hawai'i, for field research permits and access, and L. Durand, D. Feinholz, R. Langston, P. Nilsson, D. Foote, and especially K. Heckman, S. McDaniel, L. Wilson, and E. McDaniels for invaluable assistance. The following people assisted with arthropod identifications: K. Arakaki, M. Arnedo, M. Asche, J. Beatty, J. Garb, M. Gates, G. Gibson, R. Gillespie, J. Huber, E. Mockford, J. Noyes, D. Percy, D. Polhemus, D. Preston, G. A. Samuelson, C. Tauber, and A. Vandergast. We are grateful to R. Kinzie, J. Ewel, S. Cordell, and two anonymous reviewers who improved the manuscript with critical comments. We acknowledge funding from training grants from the John D. and Catherine T. MacArthur Foundation and NSF DGE9355055 and DUE-9979656 to the Center for Conservation Research and Training at the University of Hawai'i at Mânoa, an EPA Science to Achieve Results (STAR) graduate fellowship, and research grants from Sigma Xi and the NSF DDIG programme (DEB-0073055).

\section{References}

Albrectsen, B.R., Gardfjell, H., Orians, C.M., Murray, B. \& Fritz, R.S. (2004) Slugs, willow seedlings and nutrient fertilization: intrinsic vigor inversely affects palatability. Oikos, 105, 268-278.

Alyokhin, A.V., Yang, P. \& Messing, R.H. (2004) Oviposition of the invasive two-spotted leafhopper on an endemic tree: effects of an alien weed, foliar pubescence, and habitat humidity. Journal of Insect Science, 4, 1-7.

Anderson, M.J. (2000) DISTLM: a FORTRAN Computer Program to Calculate a Distance-based Multivariate Analysis for a Linear Model, Version 2. Department of Statistics, University of Auckland, Auckland, New Zealand. 
Anderson, M.J. (2001) A new method for non-parametric multivariate analysis of variance. Austral Ecology, 26, 32-46.

Andres, M.R. \& Connor, E.F. (2003) The community-wide and guild-specific effects of pubescence on the folivorous insects of manzanitas Arctostaphylos spp. Ecological Entomology, 28, 383-396.

Ball, J.P., Danell, K. \& Sunesson, P. (2000) Response of a herbivore community to increased food quality and quantity: an experiment with nitrogen fertilizer in a boreal forest. Journal of Applied Ecology, 37, 247-255.

Christiansen, K. \& Bellinger, P. (1992) Collembola. Insects of Hawai'i, Vol. 15. University of Hawaii Press, Honolulu, Hawaii. Clarke, K.R. (2001) PRIMER for Windows, Version 5.0. PRIMER-E Ltd, Plymouth, U.K.

Coley, P.D. \& Barone, J.A. (1996) Herbivory and plant defenses in tropical forests. Annual Review of Ecology and Systematics, 27, 305-335.

Colwell, R.K. (1997) Biota: the Biodiversity Database Manager, Version 1.0. Sinauer Associates, Sunderland, Massachusetts.

Cordell, S., Goldstein, G., Meinzer, F.C. \& Vitousek, P.M. (2001) Regulation of leaf life-span and nutrient-use efficiency of Metrosideros polymorpha trees at two extremes of a long chronosequence in Hawaii. Oecologia, 127, 198-206.

Cordell, S., Goldstein, G., Mueller-Dombois, D., Webb, D. \& Vitousek, P.M. (1998) Physiological and morphological variation in Metrosideros polymorpha, a dominant Hawaiian tree species, along an altitudinal gradient: the role of phenotypic plasticity. Oecologia, 113, 188-196.

Corn, C.A. \& Hiesey, W.M. (1973) Altitudinal variation in Hawaiian Metrosideros. American Journal of Botany, 60, 991-1002.

Cornell, H.V. (1989) Endophage-ectophage ratios and plant defense. Evolutionary Ecology, 3, 64-76.

Craig, T.P. (1994) Effects of intraspecific variation on parasitoid communities. Parasitoid Community Ecology (ed. by B. A. Hawkins and W. Sheehan), pp. 205-227. Oxford University Press, Oxford.

Dalin, P. \& Björkman, C. (2003) Adult beetle grazing induces willow trichome defence against subsequent larval feeding. Oecologia, 134, 112-118.

van Dam, N.M. \& Hare, J.D. (1998) Differences in distribution and performance of two sap-sucking herbivores on glandular and non-glandular Datura wrightii. Ecological Entomology, 23, 22-32.

Dawson, J.W. \& Stemmerman, L. (1999) Metrosideros Banks ex Gaertn. Manual of the Flowering Plants of Hawai'i (ed. by W. L. Wagner, D. R. Herbst and S. H. Sohmer), Vol. 1, pp. 964-970. Bernice P. Bishop Museum Press, Honolulu, Hawaii.

Denno, R.F., Gratton, C., Peterson, M.A., Langellotto, G.A., Finke, D.L. \& Huberty, A.F. (2002) Bottom-up forces mediate natural-enemy impact in a phytophagous insect community. Ecology, 83, 1443-1458.

Eisner, T., Eisner, M. \& Hoebeke, E.R. (1998) When defense backfires: detrimental effect of a plant's protective trichomes on an insect beneficial to the plant. Proceedings of the National Academy of Sciences of the United States of America, 95, 4410-4414.

Ezcurra, E., Gómez, J.C. \& Becerra, J. (1987) Diverging patterns of host use by phytophagous insects in relation to leaf pubescence in Arbutus xalapensis (Ericaceae). Oecologia, 72, 479-480.

Fagan, W.F., Siemann, E.H., Mitter, C., Denno, R.F., Huberty, A.F., Woods, H.A. et al. (2002) Nitrogen in insects: implications for trophic complexity and species diversification. American Naturalist, 160, 784-802.
Forkner, R.E. \& Hare, J.D. (2000) Genetic and environmental variation in acyl glucose ester production and glandular and nonglandular trichome densities in Datura wrightii. Journal of Chemical Ecology, 26, 2801-2823.

Forkner, R.E. \& Hunter, M.D. (2000) What goes up must come down? Nutrient addition and predation pressure on oak herbivores. Ecology, 81, 1588-1600.

Forkner, R.E., Marquis, R.J. \& Lill, J.T. (2004) Feeny revisited: condensed tannins as anti-herbivore defences in leaf-chewing herbivore communities of Quercus. Ecological Entomology, 29, 174-187.

Fretz, J.S. (2000) Relationship of canopy arthropod prey to distribution and life history of the Hawai'i 'akepa. PhD Dissertation, University of Hawai'i at Manoa, Honolulu, Hawai'i.

Gagné, W.C. (1979) Canopy-associated arthropods in Acacia koa and Metrosideros tree communities along an altitudinal transect on Hawaii island. Pacific Insects, 21, 56-82.

Geeske, J., Aplet, G. \& Vitousek, P.M. (1994) Leaf morphology along environmental gradients in Hawaiian Metrosideros polymorpha. Biotropica, 26, 17-22.

Gruenhagen, N.M. \& Perring, T.M. (1999) Velvetleaf: a plant with adverse impacts on insect natural enemies. Environmental Entomology, 28, 884-889.

Gruner, D.S. (2003) Regressions of length and width to predict arthropod biomass in the Hawaiian Islands. Pacific Science, 57, $325-336$.

Gruner, D.S. (2004a) Arthropods from 'ohi'a lehua (Myrtaceae: Metrosideros polymorpha), with new records for the Hawaiian Islands. Bishop Museum Occasional Papers, 78, 33-52.

Gruner, D.S. (2004b) Attenuation of top-down and bottom-up forces in a complex terrestrial community. Ecology, 85, 3010-3022.

Gruner, D.S. (2004c) Local and regional influences on the arthropod diversity and community structure of Metrosideros polymorpha (Myrtaceae) in the Hawaiian Islands. PhD Dissertation, University of Hawai'i at Manoa, Honolulu, Hawai'i.

Haddad, N.M., Haarstad, J. \& Tilman, D. (2000) The effects of long-term nitrogen loading on grassland insect communities. Oecologia, 124, 73-84.

Halaj, J. \& Wise, D.H. (2002) Impact of a detrital subsidy on trophic cascades in a terrestrial grazing food web. Ecology, 83, $3141-3151$.

Hare, J.D. \& Elle, E. (2002) Variable impact of diverse insect herbivores on dimorphic Datura wrightii. Ecology, 83, 2711-2720.

Hartley, S.E. (1998) The chemical composition of plant galls: are levels of nutrients and secondary compounds controlled by the gall-former? Oecologia, 113, 492-501.

Hartley, S.E. \& Crawley, M.J. (1997) Plant chemistry and herbivory, or why the world is green. Plant Ecology (ed. by M. J. Crawley), pp. 284-324. Blackwell Science, Cambridge, Massachusetts.

Hobbie, S.E. (2000) Interactions between litter lignin and soil nitrogen availability during leaf litter decomposition in a Hawaiian montane forest. Ecosystems, 3, 484-494.

Howarth, F.G. (1990) Hawaiian terrestrial arthropods: an overview. Bishop Museum Occasional Papers, 30, 4-26.

Huberty, A.F. \& Denno, R.F. (2004) Plant water stress and its consequences for herbivorous insects: a new synthesis. Ecology, 85, 1383-1398.

Hurd, L.E. \& Wolf, L.L. (1974) Stability in relation to nutrient enrichment in arthropod consumers of old-field successional ecosystems. Ecological Monographs, 44, 465-482.

James, S.A., Puttock, C.F., Cordell, S. \& Adams, R.P. (2004) Morphological and genetic variation in Metrosideros 
polymorpha (Myrtaceae) on Hawai'i. New Zealand Journal of Botany, 42, 263-270.

Juniper, B. \& Southwood, T.R.E., eds (1986) Insects and the Plant Surface. Edward Arnold, London.

Keinanen, M., Julkunen-Tiitto, R., Mutikainen, P., Walls, M., Ovaska, J. \& Vapaavuori, E. (1999) Trade-offs in phenolic metabolism of silver birch: effects of fertilization, defoliation, and genotype. Ecology, 80, 1970-1986.

Kirchner, T.B. (1977) The effects of resource enrichment on the diversity of plants and arthropods in a shortgrass prairie. Ecology, 58, 1334-1344.

Kitayama, K. \& Mueller-Dombois, D. (1992) Vegetation of the wet windward slope of Haleakala, Maui, Hawaii. Pacific Science, 46, 197-220.

Kitayama, K., Pattison, R., Cordell, S., Webb, D. \& MuellerDombois, D. (1997) Ecological and genetic implications of foliar polymorphism in Metrosideros polymorpha Gaud. (Myrtaceae) in a habitat matrix on Mauna Loa, Hawaii. Annals of Botany, 80, 491-497.

Kytö, M., Niemela, P. \& Larsson, S. (1996) Insects on trees: population and individual response to fertilization. Oikos, $\mathbf{7 5}$, 148-159.

Langellotto, G.A. \& Denno, R.F. (2004) Responses of invertebrate natural enemies to complex-structured habitats: a metaanalytical synthesis. Oecologia, 139, 1-10.

Lee, M.A.B. (1981) Insect damage to leaves of two varieties of Metrosideros collina subsp. polymorpha. Pacific Science, 35, 89-92.

Legendre, P. \& Gallagher, E.D. (2001) Ecologically meaningful transformations for ordinations of species data. Oecologia, 129, 271-280.

Legendre, P. \& Legendre, L. (1998) Numerical Ecology, 2nd English edn. Elsevier Science, Amsterdam.

Levin, D.A. (1973) The role of trichomes in plant defense. Quarterly Review of Biology, 48, 3-15.

Levine, J.M., Hacker, S.D., Harley, C.D.G. \& Bertness, M.D. (1998) Nitrogen effects on an interaction chain in a salt marsh community. Oecologia, 117, 266-272.

Magurran, A.E. (1988) Ecological Diversity and its Measurement. Princeton University Press, Princeton, New Jersey.

Mattson, W.J. (1980) Herbivory in relation to plant nitrogen content. Annual Review of Ecology and Systematics, 11, 119-61.

Mattson, W.J., Lawrence, R.K., Haack, R.A., Herms, D.A. \& Charles, P.-J. (1988) Defensive strategies of woody plants against different insect-feeding guilds in relation to plant ecological strategies and intimacy of association with insects. Mechanisms of Woody Plant Defenses Against Insects: Search for Pattern (ed. by W. J. Mattson, J. Levieux and C. BernardDagan), pp. 3-38. Springer, New York.

McArdle, B.H. \& Anderson, M.J. (2001) Fitting multivariate models to community data: a comment on distance-based redundancy analysis. Ecology, 82, 290-297.

McCabe, D.J. \& Gotelli, N.J. (2000) Effects of disturbance frequency, intensity, and area on assemblages of stream macroinvertebrates. Oecologia, 124, 270-279.

Melcher, P.J., Cordell, S., Jones, T.J., Scowcroft, P.G., Niemczura, W., Giambelluca, T.W. et al. (2000) Supercooling capacity increases from sea level to tree line in the Hawaiian tree species Metrosideros polymorpha. International Journal of Plant Sciences, 161, 369-379.

Moon, D.C., Rossi, A.M. \& Stiling, P. (2000) The effects of abiotically induced changes in host plant quality (and morphology) on a salt marsh planthopper and its parasitoid. Ecological Entomology, 25, 325-331.
Moon, D.C. \& Stiling, P. (2002) The effects of salinity and nutrients on a tritrophic salt-marsh system. Ecology, 83, 2465-2476.

Nakamura, M., Miyamoto, Y.\& Ohgushi, T. (2003) Gall initiation enhances the availability of food resources for herbivorous insects. Functional Ecology, 17, 851-857.

Nyman, T. \& Julkunen-Tiitto, R. (2000) Manipulation of the phenolic chemistry of willows by gall-inducing sawflies. Proceedings of the National Academy of Sciences of the United States of America, 97, 13184-13187.

Orians, C.M. \& Jones, C.G. (2001) Plants as resource mosaics: a functional model for predicting patterns of within-plant resource heterogeneity to consumers based on vascular architecture and local environmental variability. Oikos, 94, 493-504.

Pillemer, E.A. \& Tingey, W.M. (1976) Hooked trichomes: a physical plant barrier to a major agricultural pest. Science, 193, 482-484.

Pullin, A.S. \& Gilbert, J.E. (1989) The stinging nettle, Urtica dioica, increases trichome density after herbivore and mechanical damage. Oikos, 54, 275-280.

Raich, J.W., Russell, A.E. \& Vitousek, P.M. (1997) Primary productivity and ecosystem development along an elevational gradient on Mauna Loa, Hawai'i. Ecology, 78, 707-721.

Ritchie, M.E. (2000) Nitrogen limitation and trophic vs. abiotic influences on insect herbivores in a temperate grassland. Ecology, 81, 1601-1612.

Roda, A., Nyrop, J., English-Loeb, G. \& Dicke, M. (2001) Leaf pubescence and two-spotted spider mite webbing influence phytoseiid behavior and population density. Oecologia, 129, 551-560.

Root, R.B. (1973) Organization of a plant-arthropod association in simple and diverse habitats: the fauna of collards (Brassica oleracea). Ecological Monographs, 43, 95-124.

Roy, B.A., Stanton, M.L. \& Eppley, M. (1999) Effects of environmental stress on leaf hair density and consequences for selection. Journal of Evolutionary Biology, 12, 1089-1103.

SAS (2001) SAS for Windows, Version 8.02. SAS Institute Inc., Cary, North Carolina.

Scheu, S. \& Schaeffer, M. (1998) Bottom-up control of the soil macrofauna community in a beechwood on limestone: manipulation of food resources. Ecology, 79, 1573-1585.

Schoener, T.W. (1987) Leaf pubescence in buttonwood: community variation in a putative defense against defoliation. Proceedings of the National Academy of Sciences of the United States of America, 84, 7992-7995.

Sedlacek, J.D., Barrett, G.W. \& Shaw, D.R. (1988) Effects of nutrient enrichment on the Auchenorrhyncha (Homoptera) in contrasting grassland communities. Journal of Applied Ecology, 25, 537-550.

Siemann, E. (1998) Experimental tests of effects of plant productivity and diversity on grassland arthropod diversity. Ecology, 79, 2057-70.

Spiller, D.A. \& Agrawal, A.A. (2003) Intense disturbance enhances plant susceptibility to herbivory: natural and experimental evidence. Ecology, 84, 890-897.

Srivastava, D.S. \& Lawton, J.H. (1998) Why more productive sites have more species: an experimental test of theory using tree-hole communities. American Naturalist, 152, 510-529.

Stein, J.D. (1983) Insects infesting Acacia koa (Legumosae) and Metrosideros polymorpha (Myrtaceae) in Hawaii: an annotated list. Proceedings of the Hawaiian Entomological Society, 24, 305-316.

Stemmermann, R.L. (1983) Ecological studies of Hawaiian Metrosideros in a successional context. Pacific Science, 37, 361-373. 
Stipanovic, R.D. (1983) Function and chemistry of plant trichomes and glands in insect resistance: protective chemicals in plant epidermal glands and appendages. Plant Resistance to Insects (ed. by P. A. Hedin), pp. 69-100. American Chemical Society, Washington, DC.

Strong, D.R., Lawton, J.H. \& Southwood, T.R.E. (1984) Insects on Plants: Community Patterns and Mechanisms. Blackwell Scientific, Oxford.

Swezey, O.H. (1954) Forest Entomology in Hawaii. Special Publication 76, Bishop Museum, Honolulu, Hawaii.

Thornton, I.W.B. (1985) The geographical and ecological distribution of arboreal Psocoptera. Annual Review of Entomology, 30, 175-196.

Turnipseed, S.G. (1977) Influence of trichome variations on populations of small phytophagous insects in soybean. Environmental Entomology, 6, 815-817.

Van Lenteren, J.C., Hua, L.Z., Kamerman, J.W. \& Rumei, X. (1995) The parasite-host relationship between Encarsia formosa (Hym., Aphelinidae) and Trialeurodes vaporariorum (Hom., Aleyrodidae). XXVI. Leaf hairs reduce the capacity of Encarsia to control greenhouse whitefly on cucumber. Journal of Applied Entomology, 119, 553-559.

Vitousek, P.M. (1998) Foliar and litter nutrients, nutrient resorption, and decomposition in Hawaiian Metrosideros polymorpha. Ecosystems, 1, 401-407.
Waide, R.B., Willig, M.R., Steiner, C.F., Mittelbach, G., Gough, L., Dodson, S.I. et al. (1999) The relationship between productivity and species richness. Annual Review of Ecology and Systematics, 30, 257-300.

Waring, G.L. \& Cobb, N.S. (1992) The impact of plant stress on herbivore population dynamics. Insect-Plant Interactions (ed. by E. Bernays), Vol. 4, pp. 167-226. CRC Press, Ann Arbor, Michigan.

Wellso, S.G. \& Hoxie, R.P. (1982) The influence of environment on the expression of trichomes in wheat. Crop Science, 22, 879-886.

White, T.C.R. (1984) The abundance of invertebrate herbivores in relation to the availability of nitrogen in stressed food plants. Oecologia, 63, 90-105.

Whittaker, R.J. \& Heegaard, E. (2003) What is the observed relationship between species richness and productivity? Comment. Ecology, 84, 3384-3390.

Wilkens, R.T., Shea, G.O., Halbreich, S. \& Stamp, N.E. (1996) Resource availability and the trichome defenses of tomato plants. Oecologia, 106, 181-191.

Wright, I.J. \& Cannon, K. (2001) Relationships between leaf lifespan and structural defences in a low-nutrient, sclerophyll flora. Functional Ecology, 15, 351-359.

Accepted 18 February 2005 


\section{Appendix}

Arthropod species sampled from Metrosideros polymorpha clipping samples in 1999 and 2000. Also listed are residency status (I, historically introduced; N, native; U, undetermined); trophic level assignments (d, detritivore; h, herbivore; c, carnivore; t, tourist or undetermined); total abundance (Abund.); and loadings with axis 1 and 2 of the redundancy analysis (see Fig. 5). Boldface and numbered trophic assignments refer to labels of species vectors in Fig. 5b. Taxa are listed in alphabetical order within each decreasing taxonomic rank without regard to phylogenetic relationships.

\begin{tabular}{|c|c|c|c|c|c|c|c|}
\hline Order & Family & Genus species (author) & Origin & Trophic & Abund. & RDA1 & RDA2 \\
\hline \multicolumn{8}{|c|}{ Subphylum Chelicerata: class Arachnida } \\
\hline Acari & Acari f. & Acari g. sp. 2 & $\mathrm{U}$ & $\mathrm{t}$ & 8 & 0.021 & 0.145 \\
\hline Acari & Acari f. & Acari g. sp. 4 & $\mathrm{U}$ & $\mathrm{t}$ & 3 & -0.006 & -0.045 \\
\hline Acari & Acari f. & Acari g. sp. 5 & $\mathrm{U}$ & $\mathrm{t}$ & 4 & 0.019 & -0.029 \\
\hline Acari & Acari f. & Acari g. sp. 7 & $\mathrm{U}$ & $\mathrm{t}$ & 10 & -0.075 & 0.050 \\
\hline Acari & Acari f. & Acari g. sp. 9 & $\mathrm{U}$ & $\mathrm{t}$ & 1 & 0.003 & 0.029 \\
\hline Acari & Acari f. & Acari g. sp. 10 & $\mathrm{U}$ & $\mathrm{t}$ & 5 & -0.008 & 0.005 \\
\hline Acari & Acari f. & Acari g. sp. 12 & $\mathrm{U}$ & $\mathrm{t}$ & 4 & 0.034 & -0.087 \\
\hline Acari & Acari f. & Acari g. sp. 13 & $\mathrm{U}$ & $\mathrm{t}$ & 1 & -0.019 & -0.014 \\
\hline Acari & Acari f. & Acari g. sp. 14 & $\mathrm{U}$ & $\mathrm{t}$ & 1 & -0.019 & -0.013 \\
\hline Acari & Anystidae & Anystidae g. sp. 1 & I & c3 & 397 & 0.167 & 0.696 \\
\hline Araneae & Araneidae & Araneus emmae Simon, 1900 & $\mathrm{~N}$ & c & 1 & 0.009 & -0.023 \\
\hline Araneae & Linyphiidae & Erigone autumnalis Emerton, 1882 & I & $\mathrm{c}$ & 96 & -0.115 & 0.071 \\
\hline Araneae & Linyphiidae & Linyphiidae g. sp. 1 & I & $\mathrm{c}$ & 9 & -0.062 & 0.028 \\
\hline Araneae & Linyphiidae & Linyphiidae g. sp. 2 & I & $\mathrm{c}$ & 13 & -0.150 & -0.108 \\
\hline Araneae & Miturgidae & Cheiracanthium mordax L. Koch, 1866 & I & $\mathrm{c}$ & 37 & -0.070 & -0.022 \\
\hline Araneae & Philodromidae & Pagiopalus atomarius Simon, 1900 & $\mathrm{~N}$ & $\mathrm{c}$ & 44 & 0.011 & -0.178 \\
\hline Araneae & Salticidae & Havaika sp. 3 & $\mathrm{~N}$ & $\mathrm{c}$ & 21 & 0.005 & -0.067 \\
\hline Araneae & Tetragnathidae & Tetragnatha acuta Gillespie, 1992 & $\mathrm{~N}$ & c1 & 108 & 0.000 & 0.401 \\
\hline Araneae & Tetragnathidae & Tetragnatha anиenue Gillespie, 2002 & $\mathrm{~N}$ & $\mathrm{c}$ & 1 & 0.006 & 0.058 \\
\hline Araneae & Tetragnathidae & Tetragnatha quasimodo Gillespie, 1991 & $\mathrm{~N}$ & $\mathrm{c}$ & 19 & -0.024 & -0.075 \\
\hline Araneae & Theridiidae & Achaearanea cf. riparia (Blackwall, 1834) & I & $\mathrm{c}$ & 63 & -0.093 & -0.050 \\
\hline Araneae & Theridiidae & Theridion melinum Simon, 1900 & $\mathrm{~N}$ & $\mathrm{c}$ & 5 & -0.031 & 0.006 \\
\hline Araneae & Theridiidae & Theridion praetextum Simon, 1900 & $\mathrm{~N}$ & $\mathrm{c}$ & 1 & 0.011 & -0.029 \\
\hline Araneae & Thomisidae & Misumenops anguliventris (Simon, 1900) & $\mathrm{N}$ & c2 & 96 & 0.219 & 0.242 \\
\hline Araneae & Thomisidae & Misumenops facundus (Suman, 1970) & $\mathrm{N}$ & $\mathrm{c}$ & 93 & -0.019 & -0.246 \\
\hline \multicolumn{8}{|c|}{ Subphylum Atelocerata: class Insecta } \\
\hline Coleoptera & Carabidae & Mecyclothorax deverilli (Blackburn, 1879) & $\mathrm{N}$ & $\mathrm{c}$ & 4 & -0.021 & -0.076 \\
\hline Coleoptera & Elateridae & Eopenthes tinctus Sharp, 1908 & $\mathrm{~N}$ & $\mathrm{c}$ & 2 & -0.014 & 0.027 \\
\hline Coleoptera & Nitidulidae & Eupetinus striatus (Sharp), 1881 & $\mathrm{~N}$ & $\mathrm{~d}$ & 5 & 0.035 & 0.000 \\
\hline Coleoptera & Staphylinidae & Anotylus sp. 2 & I & c & 1 & 0.003 & 0.029 \\
\hline Coleoptera & Staphylinidae & Oligota glabra Sharp, 1880 & $\mathrm{~N}$ & $\mathrm{c}$ & 4 & -0.016 & 0.018 \\
\hline Coleoptera & Staphylinidae & Oligota sp. 4 & $\mathrm{~N}$ & c & 17 & -0.066 & 0.256 \\
\hline Collembola & Entomobryidae & Entomobrya laha Christiansen \& Bellinger, 1992 & $\mathrm{~N}$ & d & 6 & 0.018 & 0.034 \\
\hline Collembola & Entomobryidae & Entomobrya socia (Denis, 1929) & I & $\mathrm{d}$ & 25 & -0.068 & -0.099 \\
\hline Collembola & Entomobryidae & Salina celebensis (Schaeffer, 1898) & I & d1 & 6105 & 0.828 & -0.335 \\
\hline Collembola & Entomobryidae & Tomocerus minor (Lubbock, 1862) & I & $\mathrm{d}$ & 1 & 0.007 & 0.070 \\
\hline Collembola & Isotomidae & Isotoma sensibilis Tullberg, 1876 & I & d & 4 & 0.042 & -0.064 \\
\hline Diptera & Ceratopogonidae & Forcipomyia hardyi Wirth \& Howarth, 1982 & $\mathrm{~N}$ & $\mathrm{~d}$ & 7 & 0.025 & -0.069 \\
\hline Diptera & Chironomidae & Orthocladius williamsi Hardy, 1960 & $\mathrm{~N}$ & d & 4 & -0.025 & 0.078 \\
\hline Diptera & Dolichopodidae & Eurynogaster variabilis Hardy \& Kohn, 1964 & $\mathrm{~N}$ & $\mathrm{c}$ & 6 & 0.066 & 0.107 \\
\hline Diptera & Drosophilidae & Drosophila simulans Sturtevant, 1919 & I & $\mathrm{d}$ & 1 & 0.011 & -0.028 \\
\hline Diptera & Drosophilidae & Scaptomyza infurcula Hardy, 1965 & $\mathrm{~N}$ & $\mathrm{~d}$ & 5 & 0.034 & 0.021 \\
\hline Diptera & Limoniidae & Dicranomyia variabilis (Grimshaw, 1901) & $\mathrm{N}$ & d & 4 & -0.089 & -0.064 \\
\hline Diptera & Sciaridae & Ctenosciara hawaiiensis (Hardy, 1956) & $\mathrm{N}$ & $\mathrm{d}$ & 2 & 0.015 & 0.029 \\
\hline Diptera & Sciaridae & Hyperlasion magnisensoria (Hardy, 1965) & $\mathrm{N}$ & $\mathrm{d}$ & 1 & 0.011 & -0.027 \\
\hline Diptera & Sciaridae & Sciaridae g. sp. 4 & $\mathrm{U}$ & d & 1 & 0.007 & -0.018 \\
\hline Heteroptera & Lygaeidae & Nysius blackburni White, 1881 & $\mathrm{~N}$ & $\mathrm{~h}$ & 2 & 0.003 & -0.046 \\
\hline Heteroptera & Lygaeidae & Oceanides vulcan (White, 1881) & $\mathrm{N}$ & $\mathrm{h}$ & 36 & -0.041 & 0.098 \\
\hline Heteroptera & Miridae & Hyalopeplus pellucida (Stal, 1859) & $\mathrm{N}$ & $\mathrm{h}$ & 7 & -0.088 & 0.021 \\
\hline Heteroptera & Miridae & Koanoa hawaiiensis Kirkaldy, 1902 & $\mathrm{~N}$ & $\mathrm{~h}$ & 1 & -0.012 & -0.009 \\
\hline
\end{tabular}




\begin{tabular}{|c|c|c|c|c|c|c|c|}
\hline Heteroptera & Miridae & Sarona adonias Kirkaldy, 1902 & $\mathrm{~N}$ & h3 & 80 & -0.379 & 0.238 \\
\hline Heteroptera & Nabidae & Nabis curtipennis Blackburn, 1888 & $\mathrm{~N}$ & $\mathrm{c}$ & 1 & 0.019 & -0.048 \\
\hline Heteroptera & Nabidae & Nabis 'kilauea' & $\mathrm{N}$ & $\mathrm{c}$ & 1 & -0.012 & -0.009 \\
\hline Heteroptera & Nabidae & Nabis oscillans Blackburn, 1888 & $\mathrm{~N}$ & $\mathrm{c}$ & 100 & -0.117 & 0.113 \\
\hline Homoptera & Aphididae & Greenidea formosana (Maki, 1917) & I & $\mathrm{h}$ & 10 & 0.066 & -0.170 \\
\hline Homoptera & Cicadellidae & Nesophrosyne giffardi Kirkaldy, 1910 & $\mathrm{~N}$ & h1 & 84 & 0.330 & -0.002 \\
\hline Homoptera & Cixiidae & Iolania perkinsi Kirkaldy, 1902 & $\mathrm{~N}$ & $\mathrm{~h}$ & 5 & -0.006 & -0.019 \\
\hline Homoptera & Cixiidae & Oliarus inaequalis Giffard, 1925 & $\mathrm{~N}$ & $\mathrm{~h}$ & 1 & 0.006 & 0.058 \\
\hline Homoptera & Cixiidae & Oliarus inconstans Giffard, 1925 & $\mathrm{~N}$ & $\mathrm{~h}$ & 3 & -0.007 & -0.012 \\
\hline Homoptera & Delphacidae & Leialoha hawaiiensis Muir, 1916 & $\mathrm{~N}$ & $\mathrm{~h}$ & 123 & 0.187 & -0.110 \\
\hline Homoptera & Flatidae & Siphanta acuta (Walker, 1851) & I & $\mathrm{h}$ & 48 & -0.046 & -0.151 \\
\hline Homoptera & Pseudococcidae & mealybug sp. 1 & $\mathrm{U}$ & $\mathrm{h}$ & 15 & -0.021 & -0.015 \\
\hline Homoptera & Triozidae & Kuwayama cf. minuta Crawford, 1918 & $\mathrm{~N}$ & $\mathrm{~h}$ & 1 & 0.009 & -0.023 \\
\hline Homoptera & Triozidae & Kuwayama sp. 1 & $\mathrm{~N}$ & h2 & 52 & -0.333 & 0.102 \\
\hline Homoptera & Triozidae & Kuwayama nigricapita Crawford, 1918 & $\mathrm{~N}$ & $\mathrm{~h}$ & 2 & 0.005 & 0.046 \\
\hline Homoptera & Triozidae & Trioza hawaiiensis Crawford, 1918 & $\mathrm{~N}$ & $\mathrm{~h}$ & 30 & 0.180 & 0.145 \\
\hline Homoptera & Triozidae & Trioza ohiacola Crawford, 1918 & $\mathrm{~N}$ & $\mathrm{~h}$ & 204 & 0.014 & -0.064 \\
\hline Homoptera & Triozidae & Trioza sp. 2 & $\mathrm{~N}$ & $\mathrm{~h}$ & 131 & -0.016 & -0.116 \\
\hline Homoptera & Triozidae & Trioza sp. 5 & $\mathrm{~N}$ & $\mathrm{~h}$ & 4 & 0.021 & -0.054 \\
\hline Hymenoptera & Bethyliidae & Sierola $\mathrm{sp} . \mathrm{N}$ & $\mathrm{N}$ & $\mathrm{c}$ & 4 & 0.024 & 0.016 \\
\hline Hymenoptera & Bethyliidae & Sierola sp. U & $\mathrm{N}$ & $\mathrm{c}$ & 19 & 0.100 & -0.259 \\
\hline Hymenoptera & Bethyliidae & Sierola sp. V & $\mathrm{N}$ & $\mathrm{c}$ & 3 & 0.036 & -0.015 \\
\hline Hymenoptera & Colletidae & Hylaeus pubescens (Perkins, 1899) & $\mathrm{N}$ & $\mathrm{t}$ & 1 & 0.011 & -0.029 \\
\hline Hymenoptera & Diapriidae & Trichopria nr. subtilis (Perkins, 1910) & $\mathrm{N}$ & $\mathrm{c}$ & 1 & 0.003 & 0.029 \\
\hline Hymenoptera & Dryinidae & Dicondylus perkinsi (Ashmead), 1901 & $\mathrm{~N}$ & $\mathrm{c}$ & 1 & 0.003 & 0.028 \\
\hline Hymenoptera & Encyrtidae & Anagyrus?nigricans Perkins, 1910 & $\mathrm{~N}$ & $\mathrm{c}$ & 5 & 0.010 & 0.089 \\
\hline Hymenoptera & Encyrtidae & Metaphycus?alberti (Howard, 1898) & I & $\mathrm{c}$ & 1 & 0.006 & -0.016 \\
\hline Hymenoptera & Encyrtidae & Plagiomeris hospes Timberlake, 1920 & I & $\mathrm{c}$ & 2 & 0.018 & -0.045 \\
\hline Hymenoptera & Eulophidae & Euderus metallicus (Ashmead, 1901) & I & $\mathrm{c}$ & 1 & 0.008 & -0.022 \\
\hline Hymenoptera & Eulophidae & Pauahiana swezeyi Yoshimoto, 1965 & $\mathrm{~N}$ & $\mathrm{c}$ & 14 & 0.033 & 0.249 \\
\hline Hymenoptera & Eupelmidae & Eupelmus leptophyas Perkins, 1910 & $\mathrm{~N}$ & $\mathrm{c}$ & 1 & 0.016 & -0.042 \\
\hline Hymenoptera & Ichneumonidae & Pristomerus hawaiiensis Perkins, 1910 & $\mathrm{~N}$ & $\mathrm{c}$ & 1 & 0.009 & -0.023 \\
\hline Hymenoptera & Ichneumonidae & Spolas sp. 2 & $\mathrm{~N}$ & $\mathrm{c}$ & 1 & 0.025 & -0.064 \\
\hline Hymenoptera & Mymaridae & Polynema sp. 1 & $\mathrm{~N}$ & $\mathrm{c}$ & 23 & 0.064 & -0.037 \\
\hline Hymenoptera & Scelionidae & Telenomus vulcanus Perkins, 1910 & $\mathrm{U}$ & $\mathrm{c}$ & 4 & -0.024 & 0.060 \\
\hline Lepidoptera & Carposinidae & Carposina sp. 1 & $\mathrm{~N}$ & $\mathrm{~h}$ & 14 & 0.034 & 0.021 \\
\hline Lepidoptera & Geometridae & Eupithecia monticolens Butler, 1881 & $\mathrm{~N}$ & $\mathrm{~h}$ & 7 & 0.013 & -0.136 \\
\hline Lepidoptera & Geometridae & Larentiinae g. sp. 4 & $\mathrm{U}$ & $\mathrm{t}$ & 2 & -0.024 & -0.017 \\
\hline Neuroptera & Chrysopidae & Anomalochrysa hepatica McLachlan, 1883 & $\mathrm{~N}$ & $\mathrm{c}$ & 2 & -0.009 & 0.022 \\
\hline Neuroptera & Chrysopidae & Anomalochrysa maclachlani Blackburn, 1889 & $\mathrm{~N}$ & $\mathrm{c}$ & 1 & 0.003 & 0.030 \\
\hline Neuroptera & Hemerobiidae & Hemerobius pacificus Banks, 1897 & I & $\mathrm{c}$ & 2 & -0.035 & -0.025 \\
\hline Psocoptera & Caeciliidae & Valenzuela badiostigma (Okamoto, 1910) & I & d2 & 18 & 0.151 & -0.339 \\
\hline Psocoptera & Elipsocidae & Kilauella sp. 3 & $\mathrm{~N}$ & d3 & 278 & -0.763 & -0.479 \\
\hline Psocoptera & Elipsocidae & Kilauella sp. 4 & $\mathrm{~N}$ & $\mathrm{~d}$ & 9 & 0.017 & 0.099 \\
\hline Psocoptera & Pseudocaeciliidae & Lobocaecilius monicus Lee \& Thornton, 1967 & $\mathrm{I}$ & $\mathrm{d}$ & 4 & 0.008 & -0.014 \\
\hline Psocoptera & Psocidae & Ptycta spp. & $\mathrm{N}$ & $\mathrm{d}$ & 3 & -0.009 & -0.002 \\
\hline Thysanoptera & Phlaeothripidae & Haplothrips davisi Bianchi, 1946 & $\mathrm{~N}$ & $\mathrm{~d}$ & 1 & 0.011 & -0.028 \\
\hline Thysanoptera & Thripidae & Frankliniella sp. 1 & I & $\mathrm{t}$ & 4 & 0.022 & 0.005 \\
\hline Thysanoptera & Thripidae & Heliothrips haemorrhoidalis (Bouche, 1833) & I & $\mathrm{h}$ & 1 & 0.008 & -0.022 \\
\hline \multicolumn{8}{|c|}{ ubphylum Crustacea: class Malacostraca } \\
\hline Isopoda & Porcellionidae & Porcellio scaber Latreille, 1804 & I & d4 & 225 & -0.145 & 0.356 \\
\hline
\end{tabular}

